\title{
Soybean Production and Conversion of Tropical Forest in the Brazilian Amazon: The Case of Vilhena, Rondônia
}

The recent rise in Brazilian soybean production has generated concern among the environmental community and some authors that natural tropical environments of the Amazon Basin are being converted to soybean fields. Proponents of soybean production counter that soybeans represent a viable agricultural commodity for the region; environmental concern is unwarranted, because new soybean fields are replacing already deforested or otherwise transformed lands. Both arguments have been made without comprehensive study and measure of land-use/land-cover (LULC) in areas undergoing expansion of soybean production. This case study, conducted in the municipality of Vilhena, Rondônia, Brazil, in the southwestern Amazon Basin, uses remote sensing to evaluate the LULC accompanying this municipality's large growth in soybean production from 1996 to 2001. Forests are being converted for soybean production, but most of the production increase appears attributable to slight expansion of already existing fields, conversion of already deforested land, and higher yields.

\section{INTRODUCTION}

The tremendous rise in Brazilian soybean production over the last few decades represents a significant change in the country's socioeconomic and environmental landscape (Fig. 1). Brazilian farmers may have begun cultivating soybeans as early as 1882 . By 1908, Japanese immigrant farmers in São Paulo commonly planted them. Significant production began in the 1940s and 1950s in the states of Rio Grande do Sul and Santa Catarina, although consumption of the beans - in the form of forage, green manure, and hog feed-remained local. In the early 1970s, the Brazilian soybean industry began to grow rapidly, in large part due to a rise in soybean prices caused by several events. Between 1971 and 1973, the Soviet Union purchased a major portion of the U.S. grain crop, causing a general rise in grain prices. Moreover, a particularly harsh El Niño caused the failure of the Peruvian anchovy harvest, and a related drought diminished peanut

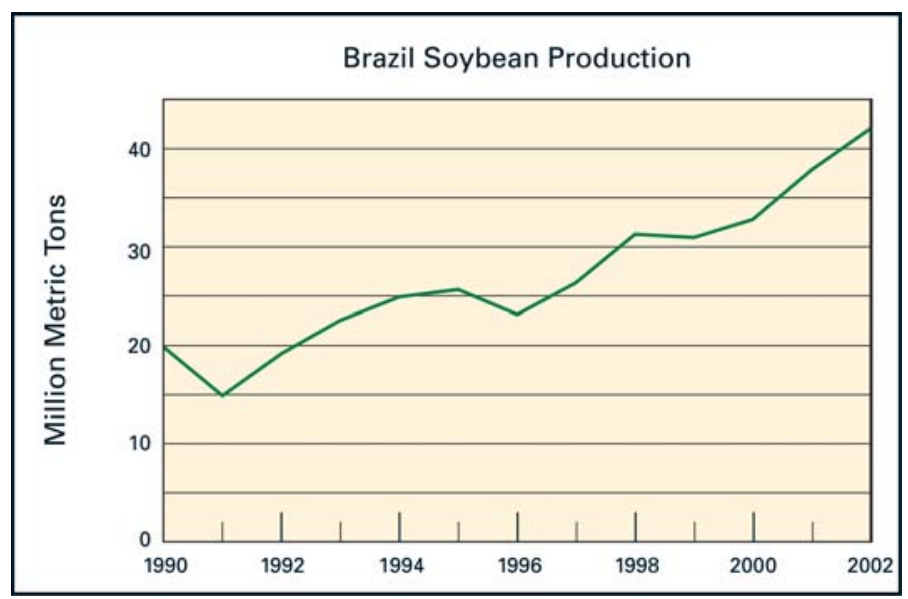

Figure 1. Soybean production in Brazil. Source: IBGE. production in central Africa. Those climate events caused severe shortages of fish meal and peanut cake, for which the only substitutes were oilseed meals such as soybean meal. The United States reacted with an embargo on its soybeans, and Brazil's soybean industry filled the demand with rapid technological improvements and geographic expansion (1-3). Global demand for soybeans has continued to grow steadily due to increased consumption of soybean oil and animal protein, and Brazilian soybean production has kept pace. As of January, 2003, Brazil was the second largest producer of soybeans in the world compared to the $43 \%$ share supplied by the United States, and Brazil's share promises to grow (4). Beginning in Brazil's south, soybean cultivation has spread steadily northward into Brazil's great central savannas (cerrados), and now, soybeans are being cultivated even farther north in the Amazon Basin.

A debate has arisen with respect to whether or not this expansion of soybean production bodes well for people and the environment. Expanded soybean production has been viewed positively by the Brazilian Agency for Agricultural Research, EMBRAPA (5), Brazilian soybean producers and transporters, and authors Mueller and Bustamante (6). Taken as a whole, those sources present the following arguments: Soybeans are an important export (34\% of global exports) (4), promising to generate US\$7 thousand million in 2003 (7). In addition, new industries accompany the expansion of soybean cultivation, generating employment opportunities. Those industries include value-added soybean crushing and soybean oil plants, and agglomeration of related activities such as transport (8). Environmentally, the crop's expansion results in negligible removal of tropical forest. Soybean cultivation will expand only into savannas and previously converted lands, such as cattle pastures, and therefore it does not pose a major new threat to the Amazonian environment.

Authors such as Branford and Freris (9), Carvalho (10), and Fearnside (11), however, do not view the crop's spectacular growth in Brazil in such positive light. They present the following narrative of rapid spread of soybean cultivation into the Amazon Basin and consequent deforestation and social problems in the region: Technological developments in Brazil have allowed soybean cultivation to expand into new regions, including those with extreme soil constraints. Brazil's agricultural researchers have been largely successful in modifying the crop and soil conditions to allow cultivation wherever Brazilians have sought to plant it. Moreover, there is no apparent waning of public or private interest in investing in soybean production and its associated industries. Beyond technology developments, Brazilians have plans to invest heavily in new infrastructure projects that will allow soybean production to be transported via Amazonian waterways, new rail systems, and paved roads to lower the cost of getting the crop from Brazil's hinterland to markets in Europe and the Pacific. Amazonia greatly attracts soybean production because land there is readily available and cheap. Because the soybeans are cultivated profitably only at a large scale, the expansion is not expected to benefit small-scale farmers. There is concern that large-scale farmers will actively force peasant farmers away from already deforested lands to still-forested regions, thus advancing the Amazon frontier. Finally, rising world 
demand for soybeans, especially as animal feed, is expected to fuel the conversion of millions of hectares of dry, semideciduous, and humid tropical forest into monocultures of soybeans.

This debate cannot move forward until systematic empirical evidence is offered concerning the human and environmental dynamics entailed in the opposing positions. That is especially true with respect to the issue of whether or not soybean fields are replacing the tropical forests of the Amazon. Fearnside (11) cites data on extreme rises in the region's production, raising concern that soybean production threatens the Amazonian environment, and he hypothesizes two possible land-use/land-cover (LULC) trajectories associated with that expansion. The first trajectory is natural land-cover to soybeans. The second is natural land-cover to cattle ranching/agriculture to soybeans. Because Fearnside is operating without direct LULC data, he cannot confirm whether one or the other is occurring or to what degree.

We share the concern that large-scale soybean agriculture promises to alter the Amazonian landscape. We are also concerned, however, with the lack of direct evidence employed in the debate. We do not know whether an increase in production necessarily means conversion of new, undisturbed, continuous tracts of humid forest or savanna vegetation. Moreover, empirical data are lacking to support the idea that soybean cultivation is merely replacing existing land uses on already deforested land. Few have attempted to directly measure, at any scale, the extent to which mechanized cropland replaces forest cover or land that has already been converted for other purposes. One exception is DeFries (12), who has used the Moderate Resolution Imaging Spectroradiometer (MODIS) to study the specific conversion of cattle pasture to mechanized cropland. In this study, however, we employ Landsat Thematic Mapper (TM) satellite imagery to ask a more basic question: In an area that has undergone rapid growth in soybean production, how much natural land cover has been converted to mechanized cropland? We present a case study of these changes in one municipality undergoing expansion of soybean production in southeastern Rondônia, Brazil.

\section{Study Area}

The municipality of Vilhena, Rondônia is our study area (Fig. 2). Vilhena's airport is located at $12.7^{\circ} \mathrm{S}, 60.1^{\circ} \mathrm{W}$ at $612 \mathrm{~m}$ elevation. Data from Rondônia government websites and a weather station in adjacent Comodoro, Mato Grosso indicate that September to April marks the rainy season, during which most of the 1800 to $2400 \mathrm{~mm}$ of annual precipitation falls; mean annual temperature is $23^{\circ} \mathrm{C}(13,14)$. Vilhena is located in a region of transition between savanna vegetation formations to the south and east, and humid tropical forests to the north $(15,16)$.

Vilhena was first established as a telegraph post by Marechal Cândido Mariano da Silva Rondon in 1911, which helped connect Mato Grosso and Amazonas states (17). From then until 1960, Vilhena consisted only of a single house and the telegraph post. In March 1960, Vilhena became home to workers who began construction of federal highway BR-29 (which would later become the BR-364) and an airstrip (18). With the completion of the highway in 1968, Vilhena, along with much of Rondônia, experienced rapid settlement $(19,20)$. Many of the new colonists were former agricultural workers from the southern state of Paraná who were attracted to 100 -ha plots being granted by the government. Many of these new farmers had either sold smaller plots in the south or lost their agricultural jobs because of lower labor requirements in an increasingly mechanized industry (19). In addition to the smaller 100-ha properties, Vilhena has a history of large landholdings dating back to the early 1970s. Less than

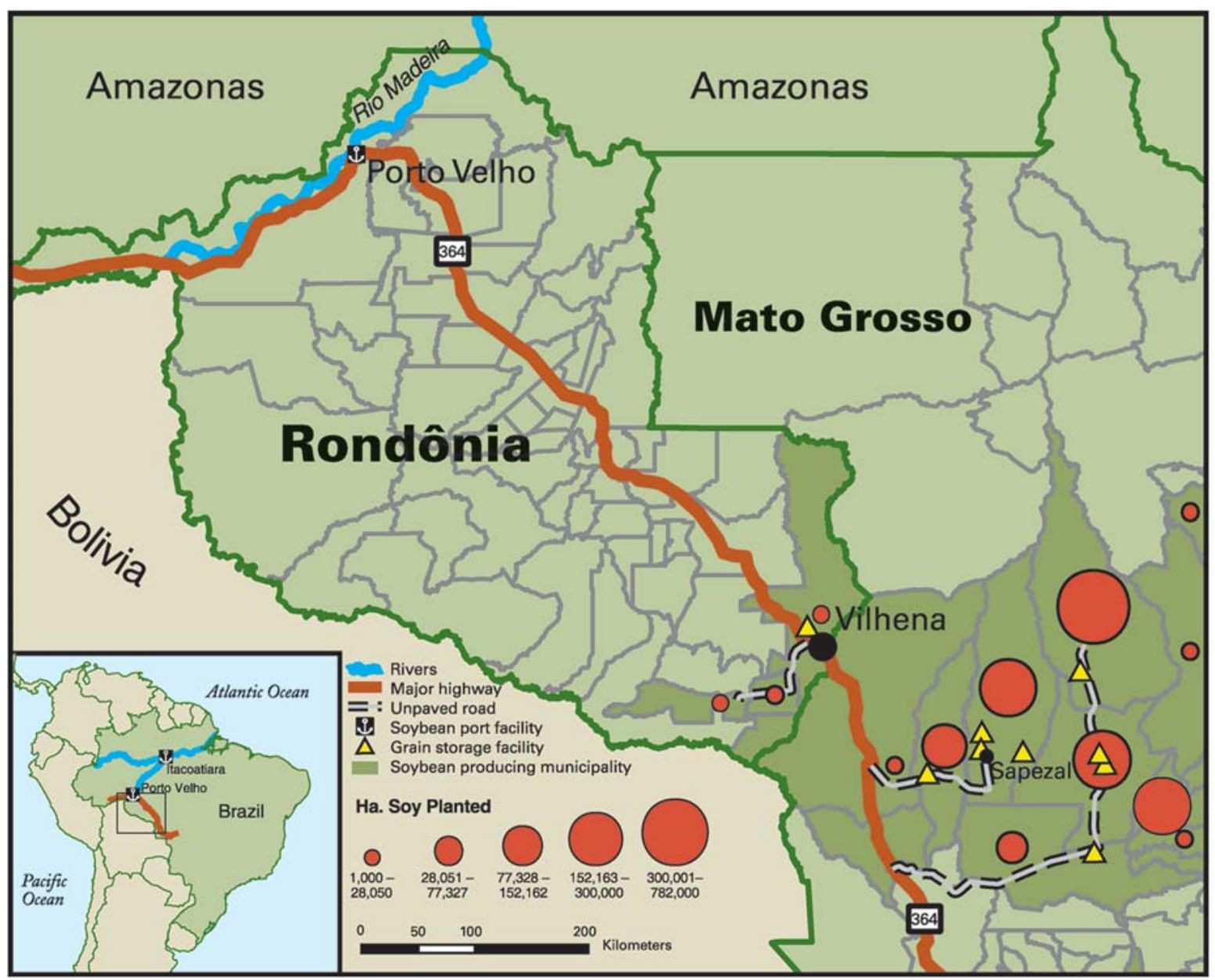

Figure 2. Situation of study area. Soybean production values reflect 2002 data. Source: IBGE. 
a decade after the completion of the highway, the federal government, still preoccupied by low population in the region, promoted the titling of large properties. More than 600 titles were granted on plots averaging 2000 ha between 1972 and 1975 in Vilhena and neighboring municipalities in southeastern Rondônia (21). Vilhena gained official municipal status in 1977 (22), and migration into the area via a newly paved BR-364 accelerated during the first half of the 1980s (23).

We chose Vilhena as our study site for a number of reasons. First, we wanted to maximize the likelihood of finding some LULC change. This could be accomplished by finding an area where soybean production has experienced rapid growth. Today, the municipality, population 53598 (24), marks the farthest expansion of well-established soybean cultivation in the western Amazon, and it is a site of continuing expansion. Fearnside (11) cites the rapid growth of soybean production in Rondonia as an example of the threat the crop poses to the Amazon, but that production was actually quite concentrated in one municipality, Vilhena. From 1991 to 2001, Vilhena's soybean production accounted for an average of $82 \%$ of Rondônia's annual production (24). The municipality is also situated directly on the major soybean export corridor in western Brazil, and such proximity to new transport infrastructure is hypothesized to result in forest conversion for soybean production. Completion of that corridor in 1996 lowered transportation costs to producers in a much larger region of production stretching from Vilhena to Sapezal, Mato Grosso. Soybeans within that region are transported by truck along the BR-364 to a grain port on the Madeira River in Porto Velho, where the beans are loaded onto barges and sent down the Madeira River to Itacoatiara, near Manaus, for processing or transport on ocean liners to European and Asian ports (Fig. 2).

Second, it was important to choose a municipality with variability in both natural and anthropogenic land covers. Vilhena historically includes a mix of cattle pasture, cropland, and various forms of natural vegetation, allowing for substantial variability. As an ecotone between Brazil's savannas to the south and the humid forests of the Amazon Basin to the north $(15,16)$, Vilhena's natural land covers range from savanna to various forms of closed canopy, semideciduous tropical forest. This allows for an understanding of the role vegetation type plays in soybean expansion. Costa's (25) data suggest that not all vegetation types are cleared at the same cost. Natural land covers, therefore, are cleared directly for soybean production only where economically feasible (e.g. where the type of natural vegetation is easily cleared mechanically or near ports and other infrastructure where the cost of deforesting dense tropical forest is offset by lower transportation costs of the soybeans). Finally, the red latosols predominating Vilhena's cultivated soils are typical for Brazil's tropical soybean-growing regions with respect to their elevated acidity, a major constraint that is corrected with application of substantial amounts of lime $(22,26)$.

\section{Methodology}

Data on production, yields, area planted for soybeans, and other agricultural activities were compiled from the Instituto Brasileiro de Geografia e Estatística (IBGE, the Brazilian Institute for Geography and Statistics) (24). The study area and soybean production areas farther east and south in the neighboring state of Mato Grosso were visited by two of the authors in the summer of 2002 for a period of $2 \mathrm{wk}$, during which interviews were conducted with ranchers, farmers, agricultural researchers, representatives of soybean storage and transport facilities, and pesticide and fertilizer dealers. The same authors traversed the main axis of soybean cultivation across the Vilhena soybean production areas, marking waypoints via global positioning system, taking photo- graphs, and writing descriptions of the landscape to aid in Landsat TM image interpretation (Landsat TM false-color composite hard copy images were taken to the field to assist in the land-cover and land-use characterization process). Data on natural vegetation types in the region were obtained from the RADAMBRASIL surveys of the late 1970s $(15,16)$.

Once we examine changes in the landscape from remotely sensed imagery, and after verifying these through personal interviews during fieldwork, it is clear that there is much more occurring in the landscape than merely soybean cultivation. It is true that the soybean market is an important driver of the expansion of agriculture. Interviews in Vilhena affirmed that any land cleared for large-scale agriculture, and any large areas of bare ground seen in our imagery, were used for soybean production. On this same land, however, farmers may plant other crops during the same year. For example, when a field is cleared for cropping, rice is often planted the first $2 \mathrm{y}$, to prepare the soil for soybeans. From then on, an increasingly important practice is to complement soybean planting with a secondary crop the same year (safrinha), typically corn, millet, sorghum, or cotton. Depending on the particular soybean seed variety planted and the farmer's individual strategy, soybeans may be planted anytime between late September and early December, and harvested between late January and early April. Soybeans in Vilhena are generally planted in a no-till fashion. About $1 \mathrm{wk}$ prior to planting, the field is sprayed with herbicide. Without plowing, the seed is then deposited directly into a shallow groove cut by the rotating blade of the planter. In short, human-influenced land covers change dramatically during the year, but they are all part of a broader system of land-use we term "mechanized annual cropping." Because we were working with only one image per year, our remote sensing methodology was not geared toward recognizing the particular reflectance values of soybeans per se as a land cover type and separating it from other types. Rather, we were interested in quantifying the area of land covers characteristic of mechanized annual cropping and any other areas that were obviously human-influenced, such as pasture, and comparing that amount of land with land that is under natural land cover.

The images used for the study were two, six-band Landsat TM (the thermal band was removed) images acquired over the state of Rondônia, Brazil (path 229/row 69) on July 6, 1996 and August 13, 2001, respectively (Fig. 3). These two dates of imagery were mostly cloud-free except for a small patch in the 2001 image. Cloud cover remains one of the biggest hurdles facing a comprehensive analysis of LULC change in tropical and subtropical environments, especially because clouds during the rainy season obscure the region (27). A subset of the region was created to include only those areas undergoing agricultural development in the municipality; thus, the urban area of Vilhena appears as a dark area in the middle of the images. Creating this subset of data reduced the overall size of the scene and increased the image classification accuracy. The images were georectified to a Universal Transverse Mercator coordinate system using ground control points and a nearest neighbor spectral interpolation procedure (28) to achieve a root mean square registration accuracy of 0.5 pixels ( 15 meters).

Once the initial image processing was completed, a postclassification change detection technique was used to assess the LULC changes over the period between 1996 and 2001. An unsupervised classification approach was applied, and land cover classes were manually assigned, a standard procedure found in similar studies (29-33). The following land cover types were identified during the image classification process: three types of woody (tree) vegetation from dense forest (semideciduous tropical forest, or cerradão) to sparse savanna (cerrado); three types of grasses ranging from scrubby grasslands to obvious human-developed pasture; and three types of human-induced land cover types 


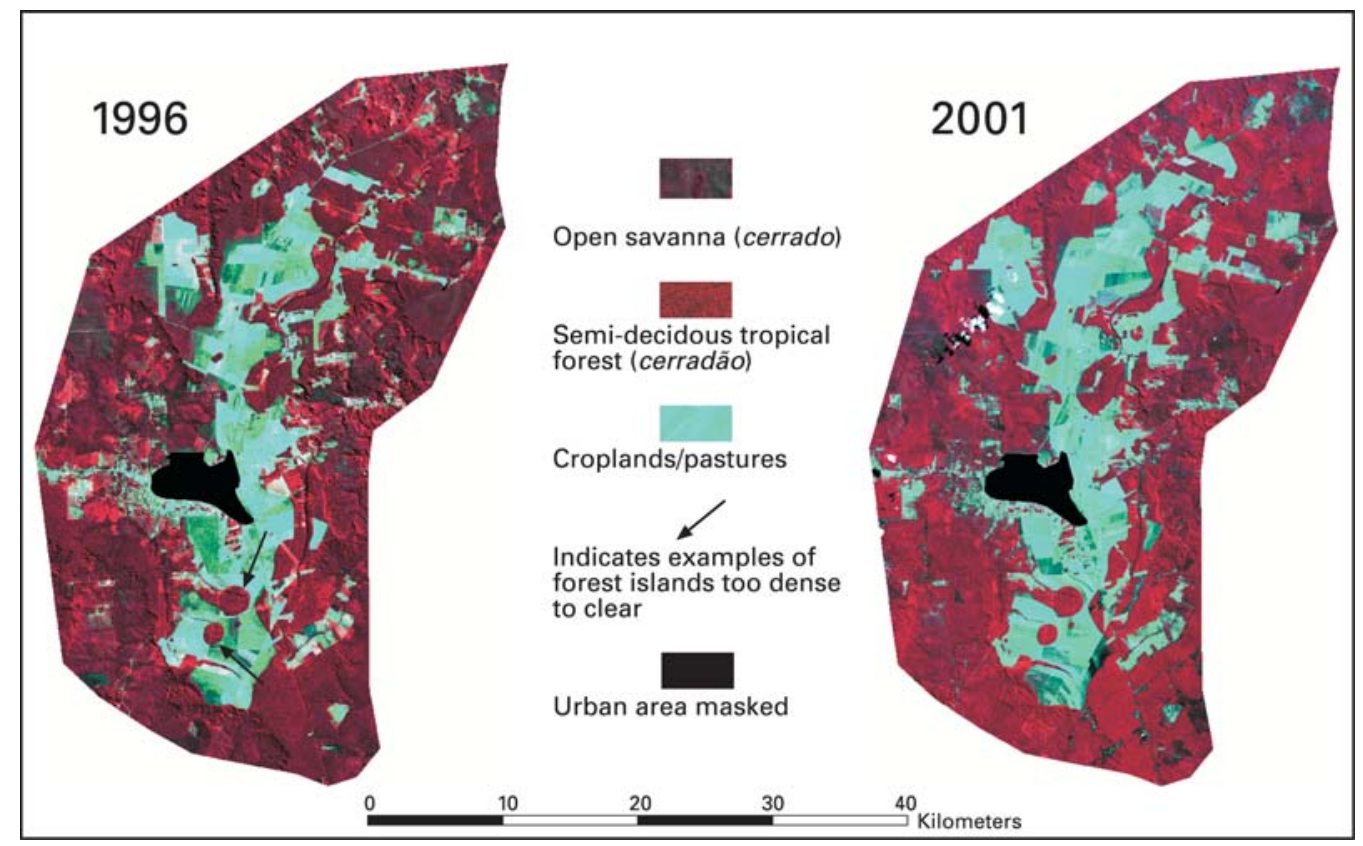

Figure 3. Raw Landsat TM data used in this study.

including weed patches and other successional land covers, dried crop cover, and bare ground. Because there was no clear-cut dividing line between the fringes of the categories, overlap exists. This problem of discriminating among subtle class differences, however, was mitigated when the nine categories were aggregated into two general classes- "natural" and "human-influenced." Any questionable areas between these two classes, especially with respect to the grasses, were assigned to the natural class. Thus, the natural class includes woody vegetation and all grasses except obvious human-developed pasture, and human-influenced includes all remaining classes. Natural vs. human-influenced classification accuracy was assessed by comparing classes derived through the classification of the satellite imagery with ground "truth" categories derived from prior in-field-level observations and notations in the field on Landsat imagery. The ground truth data and Landsat classification data were entered into an error matrix from which overall classification accuracy and the $K_{\text {hat }}$ statistic were computed (34). Based on these statistics, the overall classification accuracy was estimated to be $89.3 \%$ and the $K_{\text {hat }}$ statistic was estimated to be $86.46 \%$ for the 2001 image and $92 \%$ and $90.49 \%$, respectively, for the 1996 image.

Once this binary classification was created for each date of imagery, an areal correspondence analysis procedure was used to assess correlation between the classification of the 1996 and the 2001 imagery. This analysis was facilitated using the MATRIX module in the ERDAS IMAGINE (Leica Geosystems) image processing program. The procedure allowed us to determine which natural land-cover pixels (and type from the initial nine categories) observed on the 1996 imagery became humaninfluenced by 2001 . For example, this procedure allowed us to identify areas of dense forest that changed to some other landcover type. Image classification and change detection do not tell us about the spatial configuration of the pixels that underwent change. Upon visual examination of the change detection map, we identified three polygons in which continuous natural vegetation land cover was replaced by lands that were being used for mechanized annual cropping. We then determined the relative percentages of land-cover types converted within those polygons in order to gauge the level of homogeneity of land-cover types converted as part of new, large-scale mechanized annual cropping development.

\section{RESULTS}

IBGE data indicate that soybean production rose dramatically between 1996 and 2001 (Fig. 4), with the years 1996 and 1997 appearing as outliers. Arguably, soybean production first began its rise in Vilhena from a fairly steady level of approximately 4500 ha planted each year from 1990 to 1995, to more than three times that in 2001 (16 700 ha). Soybean yields have also seen a great increase between 1996 and 2001, from less than 2 tons ha ${ }^{-1}$, to just above 3 tons ha ${ }^{-1}$ (24).

Our remote sensing data indicate a $12.5 \%$ increase in lands dedicated to cropland -49352 ha in 1996 to 56389 ha in 2001, or about 7036 ha. Of this expansion, 2991 ha (43\%) were converted from natural land cover (1571 ha dense forest, 1421 ha less-dense forest), and 4045 ha were of already converted land covers, including differing varieties of pasture and successional vegetation, anything from heavily grazed pasturelands, poor or dried crop cover, fallowed fields, or vegetation disturbed from proximity to roads, trails, and other paths (Fig. 5).

With respect to spatial configuration of pixel change, we identified three polygons in which major, continuous tracts of natural vegetation cover were converted to mechanized annual cropping (Fig. 6). Those three regions were deemed the only significant areas of large-scale conversion of natural land cover because they were the only areas of continuous conversion that measured at least 300 ha, the minimum size for a profitable soybean field as indicated by interviews with farmers and agricultural researchers in the municipality. In polygon $1,75 \%$ of the pixels were natural land cover (dense and less-dense forest). Of that natural land, the less-dense class was $59 \%$ of the total pixels in the polygon, and the dense class was $16 \%$. This polygon is also bisected by the main road through the municipality, which may have played a role in why such a large amount of the denser land covers was converted to mechanized annual cropping. In polygon 2 , natural land cover comprised $84 \%$ of the pixels converted to mechanized annual cropping (51\% dense and 33\% less-dense forest). This polygon both borders a road and connects with or expands other preexisting fields. Finally, polygon 3 was comprised of only $35 \%$ natural land cover (4\% dense and $31 \%$ less-dense), with very scattered patches of grasses with little or no homogeneity throughout. Moreover, it appears to be an expansion of an already preexisting field. All of these polygons are situated in the north of the study area. None of them represent areas that have major patches of homogenous vegetation within. Rather, those areas contained mixed land cover types before they were converted.

In terms of other forest clearing outside the three polygons mentioned above, approximately 819 ha are areas of forest cleared for nonmechanized annual cropping purposes (road/ 

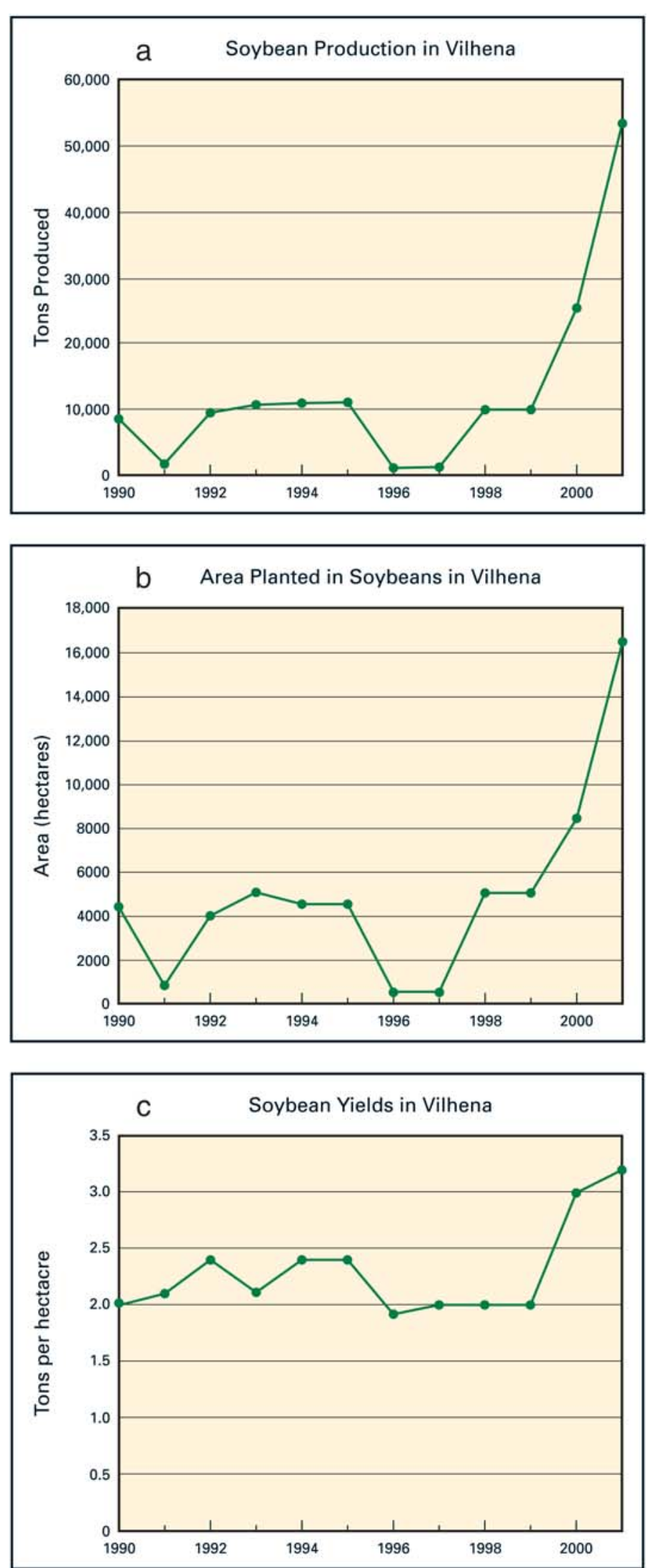

Figure 4. Soybeans in Vilhena, Rondônia, Brazil. Source: IBGE.

trails, pastures, etc). The majority of these appear in the southern part of the study area. No other significant areas of natural cover to mechanized annual cropping exist. Any additional clearing for mechanized annual cropping appears to form a category best described as "edge and corridor clearing," where farmers appear merely to clean up or straighten the edges of their fields, or small fields were expanded marginally, or corridors of cropland were made to connect already existing fields.
LULC Origin of Land Converted to Cropland

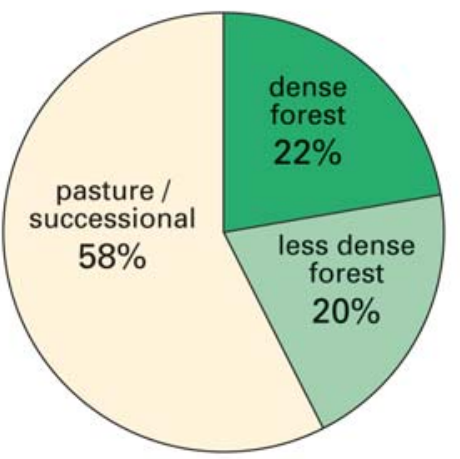

Figure 5. LULC origin of land converted to mechanized annual cropping between 1996 and 2001.

\section{DISCUSSION}

The rise in soybean production in the study area was precipitous between 1996 and 2001, but noting that rise alone reveals nothing about what land covers mechanized annual cropping replaced. In the case of Vilhena, our remote sensing analysis indicates a lack of correspondence between the amount of natural land cover converted to mechanized agriculture and the increase in area planted in soybean from published data: 2991 ha of natural land cover was removed, but published data indicate a 12200 ha increase in area planted (24). One main piece of evidence helps explain the finding. Mechanized annual cropping converted/ replaced more human-impacted land cover than natural land cover. Such a finding matches that predicted by the spatial economic model of Costa (25). Lands already deforested or developed in some way are those most likely to be converted to mechanized annual cropping, as are lands located along transportation routes or near storage facilities. Moreover, much of the concern about soybean expansion in Amazonia rests on an assumption that a rise in production is produced by an increase in area planted, ignoring the important contribution of yield increases to total production values. Such yield increases can be quite significant - from 2 to more than 3 tons ha ${ }^{-1}$ in the case of Vilhena from 1990 to 2001.

The argument has long been made that increases in crop yields actually make it possible to conserve forest cover. Consider the following calculations as that argument would apply to Vilhena. Yields actually hovered around 2.13 tons $\mathrm{ha}^{-1}$ for the entire 1990 1999 period (24) (Fig. 4). If yields were constant in 2000, it would have required a total of 11972 ha to produce the 25500 tons of soybeans reported harvested that year. Only 8500 ha were planted, however, saving 3472 ha from conversion to soybeans. The 1999-2000 jump in yields in Vilhena is extraordinary, high above the increase in Brazil as a whole, from 2.34 to 2.40 tons $\mathrm{ha}^{-1}$. However, it points to the importance of understanding how much land in Amazonia may actually not be under conversion pressure due to increases in yields, and whether yield increases are due to fortuitous weather conditions or greater investment in technology. Future work should be very careful to include as much information as possible about the various human and environmental factors leading to higher yields.

Beyond answering our basic question at the outset, our findings help draw attention to related questions that should become a part of future research. How does natural vegetation type influence whether land is converted to mechanized annual cropping? Earlier studies give contrasting hypotheses. For instance, Fearnside (11) writes that "Amazonian" forest (presumably forms of humid tropical forest) is in danger of conversion because it is less costly to develop for soybean 


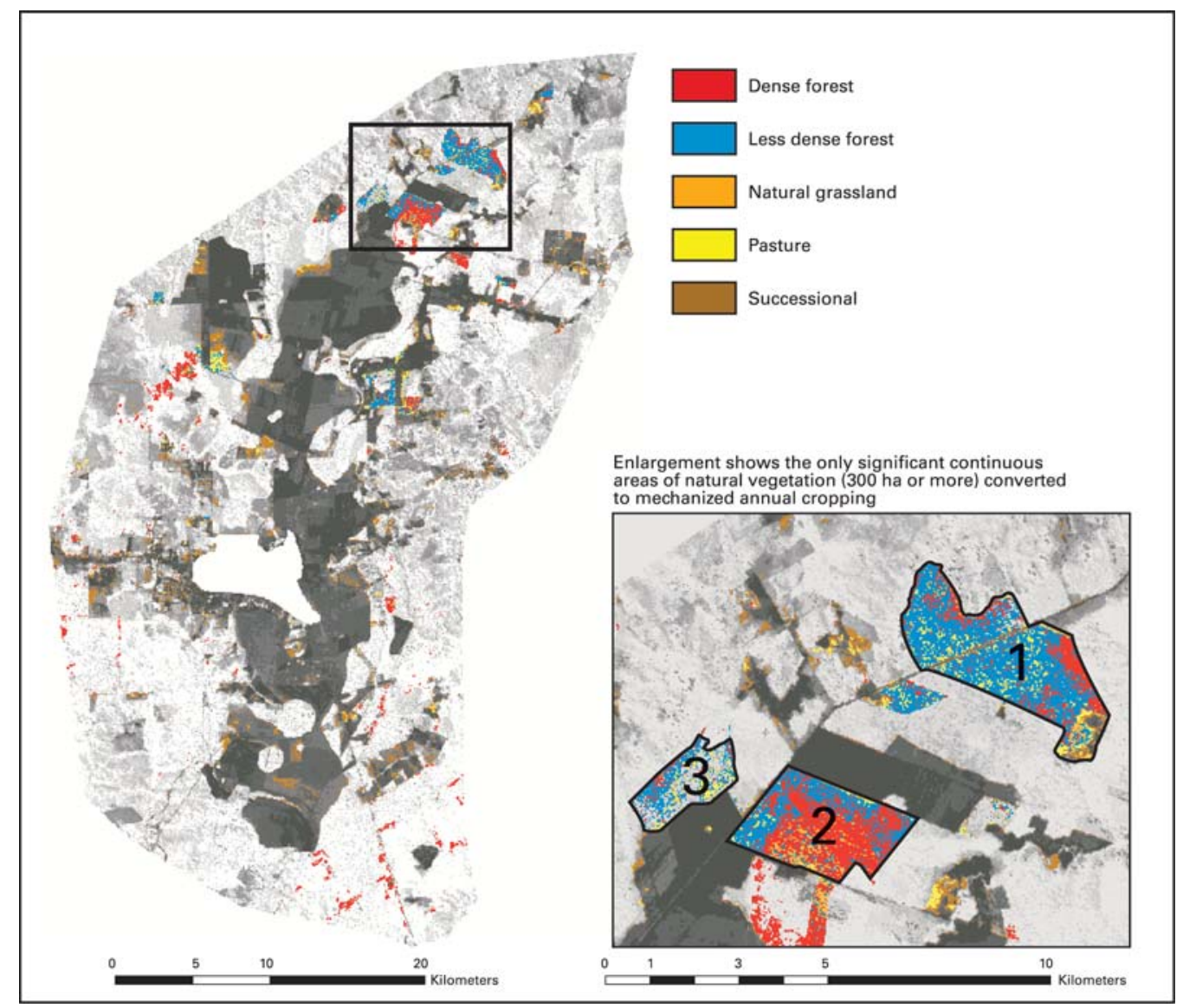

Figure 6. Change detection map (left), including enlargement of far northeast corner of study area (right), where the only largescale conversion of natural land cover for mechanized annual cropping occurred between 1996 and 2001.

production than cerrado vegetation. That is because land recently cleared of humid forest requires less inputs of lime to correct soil $\mathrm{pH}$ than is the case with soils of cerrado vegetation. In sharp contrast, Costa's (25) data from interviews with farmers and government agricultural workers and researchers indicate that humid tropical vegetation is exceedingly difficult to clear relative to cerrado. That high cost comes from the greater amount of labor and equipment required to clear humid forest. In areas of cerrado vegetation, land is easily cleared with bulldozers in a relatively short period of time due to the sparseness of trees and their diminutive stature.

Future work must recognize the heterogeneity of vegetation within the Amazon Basin and that the differential cost in clearing may affect what is or is not cleared. Distinguishing humid forests from cerrado is too simple a classification to explain LULC in the region. The terms are extremely broad for what are very diverse vegetation formations. Our findings indicate that natural cerrado vegetation in the study area cleared between 1996 and 2001 was not uniform, and that even some cerrado vegetation and semideciduous tropical forest formations, cerradão, may be cost-prohibitive to clear. The forest islands remaining in the middle of well-developed mechanized annual cropping fields are physical evidence of what interviewees claimed were areas of cerradão that were simply too costly to clear (Fig. 3). Visual inspection of the congruence between our remote sensed classification and that provided by the RADAMBRASIL (16) survey not only give us confidence in the accuracy of our classification (Fig. 7); it is further evidence that it is indeed the areas of easily cleared vegetation that are developed first in an area. Clearly, up until 2001, agriculture has spread only negligibly outside the vegetation zone the RADAMBRASIL (16) survey designated as "open savanna, with no gallery forests." Farmers may be willing to leave dense forested vegetation undeveloped even though they are, especially in the Vilhena case, near transportation routes and purchase/storage facilities. Future analyses should include more detailed understanding of vegeta- tion, especially in a way that identifies the characteristics of vegetation most associated with whether it is convertible to mechanized annual cropping. Our analysis of the three polygons of continuous conversion in the north of the study area showed quite well that considerable heterogeneity in forest types are detectable, and some measure such as density of vegetation may help explain which natural land covers are converted and which are not.

Laws governing forest use could also explain why farmers leave forested areas intact and develop only lands that are already cleared. Federal Medidas Provisórias, provisional executive orders set forth in 1996 and 1998 by Brazilian President Cardoso, require landowners to maintain at least $80 \%$ of forest lands in reserve and $20 \%$ of savanna vegetation in reserve, respectively. Our interviews with government officials in Vilhena indicate that few properties are in compliance with this law (a common situation throughout Rondônia). These same officials affirm Costa's finding (25) that the economic cost of clearing land is a major determinant of whether or not an area is cleared for mechanized annual cropping.

Study of the spatial configuration of LULC allows us to begin addressing questions about the relationship between the expansion of mechanized annual cropping and changes in land tenure. The tendency in some literature on soybean expansion is to assume that conversion to mechanized annual cropping occurs in wholesale fashion (i.e. large tracts of continuous land are cleared, and any previous activities, often assumed to be based on smallholder peasant production, are replaced by large-scale soybean cultivation). Our results from Vilhena indicate, however, that roughly half of new land for mechanized annual cropping came simply from the slight expansion of already existing fields across the municipality, often appearing as a straightening out of field edges (Fig. 6). We detected only three large polygons developed between 1996 and 2001 in which it was clear that natural vegetation became mechanized annual cropping in wholesale fashion. While the land tenure history of those tracts was not 


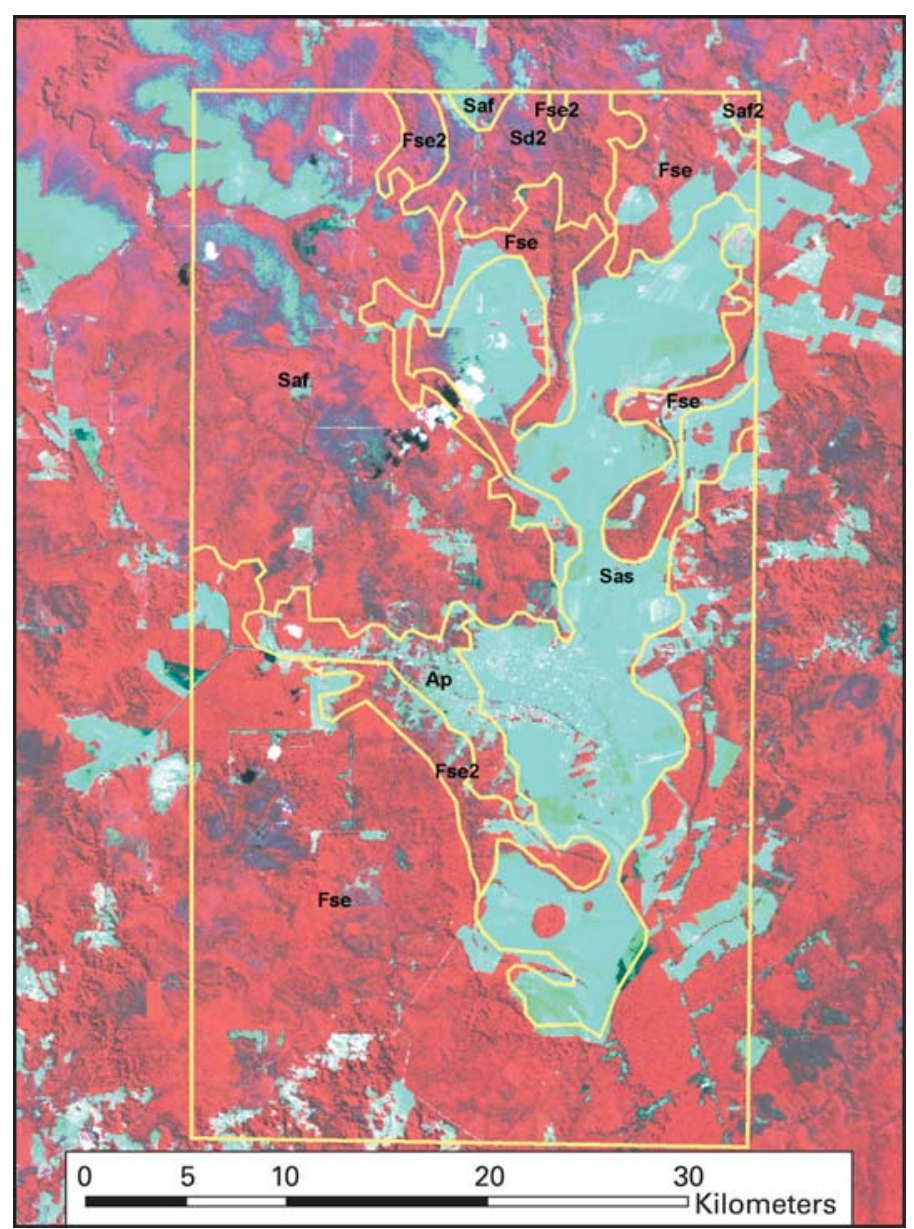

Figure 7. Overlay of natural vegetation cover from RADAMBRASIL (1979) survey on 2001 Landsat TM image. Fse and Fse2, semideciduous tropical forest; Ap, human-influenced (pasture); Sas, open savanna, no gallery forests; Saf and Saf2, open savanna, with gallery forests; Sd2, dense/closed savanna. "2" Indicates formations that are savanna/seasonal forest ecotones.

determined, the overall spatial characteristics of LULC in Vilhena do not suggest the kinds of major changes in land tenure, at times violent, that are often assumed to be associated with a rise in soybean production $(10,11)$. One alternative explanation for the rise in soybean production could be that people who already have some control over land, either as owner or farmer/renter, are investing more in their fields by straightening edges and expanding fields into new forested areas or areas that had been left fallow for a number of years. Future studies should incorporate some form of documentation of land tenure history with remote sensing to determine the relationship between changes in social relations and LULC.

Our study focused on a small, well-defined geographic area and period in order to address our basic concerns about soybean production and LULC in Amazonia. This had the advantage of allowing for the most accurate tracking of the changes, but not without some problems and limitations. Like Fearnside (11), we chose the year 1996 in selecting a baseline year for discussing the great surge in Rondonian soybean production, and we chose 2001 as the end date because it was the year for which the latest highquality image was available. The question is how to properly match in time the changes in published production figures with changes in land cover. Consider the baseline date. The years 1996 and 1997 were years when, for various local, regional, and global economic reasons, the number of hectares planted in soybean in Vilhena had dropped (35). In Vilhena, soybean production had been at a high of close to 11000 tons before dropping below 1000 tons. Though production was quite low, natural land cover had already possibly been altered years earlier to accommodate the greater production that would follow. In our effort to track changes in natural land cover, this would have the effect of underestimating the amount of land converted for mechanized agriculture. Choosing an end year for such studies is likewise problematic. Interviews with farmers and agricultural researchers in Vilhena indicate that it takes approximately 2 y or more to convert natural vegetation to soybean cultivation. Amendments must be added to the soil over this period, and nearly all remnants of woody vegetation removed before harvesters can be put in the fields. Rice is often planted during this transitional period. Thus, the three significant areas of wholesale vegetation conversion identified using the remotely sensed data may be reflected only in 2003 production figures. In fact, such an issue suggests the possibility that the entire growth of soybean production in Vilhena from 1996 to 2001 occurred without the conversion of significant new areas of natural vegetation to mechanized annual cropping. This, of course, would have the effect of overestimating the impact of mechanized annual cropping on natural land cover. Future studies in Vilhena and elsewhere in Amazonia would require a much greater investment in acquiring satellite data over a much greater period of time and with greater temporal resolution, all while finding ways to resolve the problems of cloud cover in satellite data for this region (27).

Using two observation years obviously makes it difficult to know much about human and environmental processes occurring in intervening years. This is especially true considering questions about land-use trajectories. For example, just because an area of cerrado in 1996 appears as mechanized annual cropping in 2001 does not mean that someone removed natural vegetation in order to plant soybeans. As Costa (25) predicts, between 1996 and 2001, the land may have first become cattle pasture under one owner, only later becoming mechanized annual cropping under a different owner. Knowing whether it was the intentions of land owners/ managers to convert natural vegetation just for cattle, or whether they intended all along eventually to carry out mechanized annual cropping can only be determined with in-depth interviews. Adding more and more dates to the remote sensing analysis can help resolve what the actual LULC trajectory was in these rapidly changing landscapes, but again, it is not always possible to acquire cloud-free, quality data.

Finally, as with any case study, there is the issue of whether our findings from Vilhena have external validity. We do not make the claim that soybean production and land conversion will have the same characteristics in all of Amazonia. Considering the great heterogeneity of Amazonia in terms of its natural characteristics, history of settlement, land tenure, and societal/cultural characteristics of its peoples, there is strong likelihood of finding different patterns elsewhere. We will be able to tell only by completing more case studies in significantly different regions of soybean expansion in Amazonia; for example, in northern Mato Grosso or Pará. As outlined earlier, however, characteristics of Vilhena make it a place where we would have expected a great deal of conversion of natural land cover to mechanized annual cropping, but we did not find that.

\section{Conclusion}

The amount of land in Vilhena, Rondônia dedicated to mechanized annual cropping, largely for the production of soybeans, rose dramatically between 1996 and 2001. This matches a pattern across the southern edge of the Amazon Basin, and those increases have alarmed environmentalists who are concerned that the increased production comes from the aerial expansion of annual crops and conversion of natural land cover. Proponents of the expansion of mechanized annual cropping in Vilhena and elsewhere in Amazonia respond that their activities represent an expansion of a highly productive activity on lands 
that were already disturbed in some fashion. We conclude from the Vilhena case that neither extreme is occurring. Most land converted to mechanized annual cropping was land already disturbed by modern human activity, but there was evidence in the remote sensing data that forested lands have and will experience some conversion pressure in the future.

World demand for soybeans promises to grow, and Brazil officially stands poised to meet that demand (36). Such demand will be met within the highly varied human and physical geography of Amazonia, with most places likely presenting a mix of constraints and opportunities for future development of mechanized annual cropping. For example, while a new road may bring greater market accessibility to farmers, dense and tall vegetation in the region may be too costly for all farmers to develop. A host of variables that explain what lands are developed and where remain to be explored in future case studies or systematic basin-wide research. The existence of land-use laws and enforcement, topography, availability of credit, and the right seeds are but a few variables within the human environmental system at work in mechanized annual cropping and the conversion of natural land covers. The growth of mechanized annual cropping in Amazonia will be one of the most significant factors in LULC in the region. Further research employing a remote-sensing approach, combined with attention to socioeconomic data and interviews concerning LULC, promises to supply both the environmental community and promoters of mechanized soybean and other annual cropping the empirical information required to make policy decisions regarding agricultural development and the protection of tropical ecosystems.

\section{References and Notes}

1. Banck, G.A. and den Boer, C.W.M. 1991. Sowing the Whirlwind: Soya Expansion and Social Change in Southern Brazil. CEDLA, Amsterdam.

2. Soskin, A.B. 1988. Non-Traditional Agriculture and Economic Development: The Brazilian Soybean Expansion, 1964-1982. Praeger, Westport, Connecticut.

. Warnken, P.F. 1999. The Development and Growth of the Soybean Industry in Brazil, 1st edition. Iowa State University Press, Ames, Iowa.

. USDA 2003. Soybeans: World Supply and Distribution. Counselor and Attaché Reports Foreign Agricultural Service, Cotton, Oilseeds, Tobacco and Seeds Division.

5. EMBRAPA 2002. Sistemas de Produção 1: Tecnologias de Produção de Soja-Região Central do Brasil. (Production Systems 1: Technologies of Soybean Production-Centra Region of Brazil). (In Portuguese). (http://www.cnpso.embrapa.br/download/central $\mathrm{pdf})$

6. Mueller, C.C. and Bustamante, M. 2002. Análise da Expansão da Soja no Brazil. (Analysis of the Expansion of Soybeans in Brazil). (In Portuguese). (http://www.worldbank. $\mathrm{org} / \mathrm{rfpp} /$ news/debates/mueller.pdf).

. Thompson, J. 2003. Brazil's biotech challenges. Soybean Digest Jan 1, 2003. (http:/ www.soybeandigest.com/ar/soybean_brazils_biotech_challenges).

8. Johnston, J. 2003. ADM to double Brazilian soybean crushing plant. AgWeb News, Jan 13, 2003. (http://www.agweb.com/news_show_news_article.asp?file=AgNewsArticle 200311396_5012\&articleid=94390\&newscat $=\mathrm{GN})$.

9. Branford, $\overline{\mathrm{S}}$. and Freris, N. 2000. One great big hill of beans. The Ecologist 30, 46-47.

0. Carvalho, R. 1999. A Amazônia Rumo ao 'Ciclo da Soja'. Amazônia Papers No. 2. (The Cycle of Soybean in the Amazon). (In Portuguese). Programa Amazônia, Amigos da Terra, São Paulo, Brazil. (http://www.amazonia.org.br).

11. Fearnside, P.M. 2001. Soybean cultivation as a threat to the environment in Brazil. Environ. Cons. 28, 23-38

12. DeFries, R.S. 2004. Land-Cover Changes in Mato Grosso, Brazil: Secondary Transition from Pasture to Mechanized Agriculture. Presentation at the Annual Meeting of the Association of American Geographers. March 19, 2004. Philadelphia, Pennsylvania.

13. Portal Conesul 2004. Portal Cone Sul-Nova Mídia Comunicação \& Marketing Ltda (Southern Cone Portal-New Media Communications and Marketing Limited) (In Portuguese). (http://www.portalconesul.com.br/)

14. EMBRAPA 2004. Centro Nacional de Pesquisa de Monitoramento por Satélite (National Research Center of Satelitte Monitoring). (In Portuguese). (http://www.cnpm. embrapa.br).

15. RADAMBRASIL 1979. Levantamento de Recursos Naturais. 20. (Survey of Natural Resources). Rio de Janeiro: Ministério das Minas e Energia. (In Portuguese).

16. RADAMBRASIL 1978. Levantamento de Recursos Naturais. 19. (Survey of Natural Resources). Rio de Janeiro: Ministério das Minas e Energia. (In Portuguese).

17. de Viveiros, E. 1958. Rondon Conta Sua Vida. (The Life of Rondon). Livraria São José, Rio de Janeiro. (In Portuguese).

18. Ferreira, M.R. 1961. Nas Selvas Amazônicas. (In the Amazon Jungle). Gráfica Biblos Ltda., São Paulo. (In Portuguese).

19. Mahar, D.J. 1989. Government Policies and Deforestation in Brazil's Amazon Region. The World Bank, Washington, D.C.

20. Lisboa, P. 1989. Rondônia: Colonização e Floresta. Programa do Trópico Úmido. POLONOROESTE Relatório de Pesquisa No. 9. (Rondônia: Colonization and Forest. Humid Tropics Program. Polonoroeste Research Report No. 9). CNPq, AED, Brasília. (In Portuguese).

21. Perdigão, F. and Bassegio, L. 1992. Migrantes Amazônicos-Rondônia: a Trajetória da Ilusão. (Amazonian Migrants-Rondonia: the Trajectory of Illusion). Ediç̧es Loyola, Ilusão. (Amazonian Migra

22. Fernandes, L.C. and Guimarães, S.C.P. 2001. Atlas Geoambiental de Rondônia (GeoEnvironmental Atlas of Rondônia). SEDAM, Porto Velho, Rondônia. (In Portuguese)
23. Fearnside, P.M. 1989. A Ocupação Humana de Rondônia: Impactos, Limites, Planejamento. Programa do Trópico Úmido POLONOROESTE Relatório de Pesquisa. (The Human Occupation of Rondônia: Impacts, Limits, and Planning. Humid Tropics Program. Polonoroeste Research Report). CNPq, Brasília. (In Portuguese).

24. IBGE 2003. Sistema IBGE de Recuperação Automática. Instituto Brasileiro de Geografia e Estatística. (In Portuguese). (http://www.sidra.ibge.gov.br/bda/).

25. Costa, F.G. Avaliação do Potencial de Expansão da Soja na Amazônia Legal: uma Costa, F.G. Avaliação do Potencial de Expansao da Soja na Amazonia Legal: uma Aplicação do Modelo de Von Thünen. (Evaluation of the Potential of Soybea Expansion in the Legal Amazon: An Application of the Von Thünen Model). Master's
Thesis, Escola Superior de Agricultura, Universidade de São Paulo, Piracicaba, São Thesis, Escola Superior de A

26. Calvet, J.C., Santos Alvalá, R.C., Jaubert, G., Delire, C., Nobre, C.A., Wright, I. an Noilhan, J. 1997. Mapping surface parameters for mesoscale modeling in forested and deforested South-Western Amazonia. B. Am. Meteorol. Soc. 78, 413-423.

27. Asner, G.P. 2001. Cloud cover in Landsat observations of the Brazilian Amazon. Int J. Remote Sens. 22, 3855-3862.

28. Jensen, J.R. 1996. Introductory Digital Image Processing: A Remote Sensing Perspective. Prentice Hall, Upper Saddle River, New Jersey.

29. Egbert, S.L., Lee, R-Y., Price, K.P. and Boyce, R. 1998. Mapping conservation reserve program (CRP) grasslands using multi-seasonal thematic mapper imagery. Geocarto Int $13,17-24$.

30. Jensen, J.R., Ramsey, E.W., Mackey, H.E., Christensen, E.J. and Sharitz, R.R. 1987 Inland wetland change detection using aircraft MSS data. Photogr. Engin. Remote Sens. $53,521-529$

31. Richards, J.A. 1984. Thematic mapping from multitemporal image data using the principal components transformation. Remote Sens. Environ. 16, 35-46.

32. Ichii, K., Maruyama, M. and Yamaguchi, Y. 2003. Multi-temporal analysis of deforestation in Rondônia state in Brazil using Landsat MSS, TM, ETM+ and NOAA AVHRR imagery and its relationship to changes in the local hydrological environment Int. J. Remote Sens. 24, 4467-4479.

33. Price, K.P., Pyke, D. and Mendes, L. 1992. Shrub dieback in a semiarid ecosystem: the integration of remote sensing and geographic information systems for detecting vegetation change. Photogr. Engin. Remote Sens. 58, 455-463.

34. Congalton, R.G. 1991. A review of assessment of accuracy of classifications of remotely sensed data. Photogr. Engin. Remote Sens. 49, 69-74.

35. Oliveira, S.J. de M., Godinho, V. de P.C. and Utumi, M.M. 2002. Diagnóstico da Cultura da Soja em Rondônia. (Analysis of Soy Cultivation in Rondônia). Porto Velho, Rondônia, EMBRAPA. (In Portuguese).

36. The Guardian. 2004. Lula seals deal to feed China's booming cities. The Guardian, May 28, 2004. (http://www.guardian.co.uk).

37. Acknowledgments: J Christopher Brown acknowledges the financial support of the New Faculty General Research Fund, grant 2301843 of The University of Kansas Center for Research, Inc. and collaboration with the Kansas Applied Remote Sensing Program at the University of Kansas. Matthew Koeppe thanks the Tinker Foundation for research travel funds. Darin Grauberger and student assistants at University of Kansas Cartography and GIS services helped create and assemble the figures. Thank also to Wendy Jepson and anonymous reviewers for helpful comments on an earlie draft of this article. Finally, many thanks to the farmers and agricultural researchers from Vilhena, Rondônia and personnel from the Grupo Andre Maggi for patiently answering our questions during fieldwork. Any errors remain ours.

38. First submitted 28 July 2003. Revised manuscript received 2 July 2004. Accepted for publication 25 July 2004

J. Christopher Brown is assistant professor in the Department of Geography and the Environmental Studies Program at the University of Kansas. His research focuses on the political, economic, and environmental dynamics of development in Latin America, especially the Brazilian Amazon. jcbrown2@ku.edu

Matthew Koeppe is a doctoral candidate at the University of Kansas and an International Program Specialist at NASA Headquarters in Washington, DC. His research focuses on social and environmental changes associated with the expansion of mechanized agriculture in the Brazilian Amazon. koeppe@ku.edu

Benjamin Coles is a master's candidate in Geography at the University of Kansas. His research interests include Latin American regional geography and human-environment development issues in frontier areas. prijon@ku.edu

Kevin Price is professor in the Department of Geography and the Kansas Applied Remote Sensing Program at the University of Kansas. His research interests include biogeography, landscape ecology, remote sensing, geographic information systems, and resource management. price@ku.edu

Their address: Department of Geography, 1475 Jayhawk Blvd, 230 Lindley Hall, University of Kansas, Lawrence, KS 660457613, USA. 